\title{
PUBLIKASI PENELITIAN
}

Publikasi ilmiah merupakan salah satu kunci bagi peneliti untuk menyebarluaskan sebuah temuan baru dari hasil penelitian. Publikasi ilmiah adalah sistem publikasi yang dilakukan berdasarkan per review dalam rangka untuk mencapai tingkat objektivitas setinggi mungkin. Jika sebuah penelitian hanya di jilid tebal dan disimpan dalam perpustakaan universitas atau sebuah pusat studi maka hanya dapat diakses oleh kalangan yang sangat terbatas. Sebagian besar karya akademis diterbitkan dalam jurnal ilmiah atau dalam bentuk buku. Sementara, ada jutaan orang di dunia yang sedang mencari referensi untuk mendukung riset mereka. Untuk membantu memecahkan masalah dan menciptakan solusi baru yang sedang dihadapi. Pada hakekatnya, publikasi penelitian merupakan penyerahan karya peneliti ke masyarakat melalui penerbit, maka publikasi ilmiah merupakan amal akademik bagi peneliti.

Publikasi ilmiah menjadi agenda penting bagi para akademisi, bukan hanya sebagai prasyarat semata tetapi hal tersebut juga dilakukan untuk masa depan bangsa Indonesia. Saat ini, publikasi ilmiah sedang mengalami perubahan yang besar, yang muncul akibat transisi dari format penerbitan cetak ke arah format elektronik, yang memiliki model bisnis berbeda dengan pola sebelumnya. Tren umum yang berjalan sekarang, akses terhadap jurnal ilmiah secara elektronik disediakan secara terbuka. Hal ini berarti semakin banyak publikasi ilmiah yang 
dapat diakses secara gratis melalui internet, baik yang disediakan oleh pihak penerbit jurnal, maupun yang disediakan oleh para penulis artikel jurnal itu sendiri.

Penelitian yang dipublikasikan haruslah penelitian yang original. Syarat original ini berlaku bagi substansi dan cara penyampaiannya. Substansi yang original berarti pokok bahasan dalam artikel yang akan diterbitkan belum pernah dipublikasikan sebelumnya. Substansi penelitian yang original harus diperiksa pada saat memulai penelitian. Oleh karena itu, penting sekali bahwa kita melakukan penelitian dengan baik dan segera mempublikasikannya.

Untuk sebuah penelitian yang menghasilkan invensi, peneliti memiliki peluang untuk mematenkan temuan/invensi tersebut. Dalam hal ini, mematenkan hasil penelitian adalah untuk tujuan komersial, artinya jika paten tersebut dimanfaatkan oleh industri maka peneliti akan menerima royalty atau meneria penghasilan dari penjualan paten ke industri, meskipun setelah diindustrikan juga memberikan manfaat bagi pengguna teknologi. (Setiyo, Teknik Menyusun Manuskrip dan Publikasi Imiah Internasional, 2017) Jika sebuah temuan berhasil dipatenkan dan diindustrikan, penelitian dan institusinya akan menghasilkan manfaat materiil secara langsung, yang berbeda dengan temuan penelitian yang dipublikasikan. 


\section{A. Penelitian}

Di Indonesia, istilah resmi penelitian salah satunya terdapat dalam Undang-Undang Nomor 12 Tahun 2012 tentang Pendidikan Tinggi. Penelitian merupakan kegiatan yang dilakukan menurut kaidah dan metode ilmiah secara sistematis untuk memperoleh informasi, data, dan keterangan berkaitan dengan pemahaman dan/atau pengujan suatu cabang ilmu pengetahuan dan teknologi.

Dari sekian banyak definisi penelitian, berdasarkan arti kata dalam bahasa inggris, penelitian adalah research (kegiatan mencari kembali). Karena kegiatan penelitian adalah mencari kembali maka tujuan dari sebuah pencarian adalah menemukan sesuatu dengan cara atau metode tertentu (Setiyo, Teknik Menyusun Manuskrip dan Publikasi Ilmiah Internasional, 2017).

Penelitian berdasarkan prinsip ilmiah, manfaat, etika dan norma agama, kebebasan akademik, tanggung jawab, kejujuran, kebajikan dan inovatif. Penelitian bertujuan mengembangkan ilmu agama, mengembangkan ilmu pengetahuan dan teknologi, mengembangkan budaya dan seni, mengembangkan budaya akademik dan mengatasi persoalan kehidupan dan kemanusiaan. Hasil penelitian diarahkan dalam rangka mengembangkan ilmu pengetahuan dan teknologi, serta meningkatkan kesejahteraan masyarakat dan daya saing bangsa. Hasil penelitian disebarluaskan melalui seminar, publikasi, dan paten yang dapat digunakan untuk menyampaikan hasil penelitian kepada 
masyarakat (Wahyudin, 2016).

\section{B. Publikasi Penelitian}

Menurut KBBI, publikasi bermakna pengumuman atau penerbitan. Publiksai ialah hasil tulisan atau karya tulis yang diterbitkan atau dipublikasikan. Penerbitan karya tulis dapat bersifat populer, populer-ilmiah, dan ilmiah (Nashihuddin, 2016).

Kemajuan teknologi komunikasi telah mengubah segalanya, termasuk publikasi penelitian. Pada tahun 90-an, publikasi ilmiah ditebitkan secara cetak. Sedangkan di masa kini publikasi ilmiah menuntut penerbitan secara secara elektronik (Wahyudin, 2016).

Publikasi ilmiah merupakan sistem publikasi yang dilakukan melalui proses penelitian atau pemeriksaan terhadap suatu karya ilmiah oleh pakar lain dalam bidang yang sama. Berdasarkan surat edaran Kementrian Pendidikan dan Kebudayaan Direktorat Jendral Pendidikan Tinggi Nomor: 152/E/T/2012, publikasi ilmiah menjadi syarat wajib bagi mahasiswa program Sarjana untuk memperoleh kelulusan (Yosua P.W Simaremare, 2013).

Pada awal penerbitan ilmiah, ilmuan mengirim karyakaryanya dalam bentuk naskah. Saat ini penggunaan perangkat lunak untuk mempublikasikan karya ilmiah adalah wajib. Penggunaan media online dengan internet digunakan penerbit dan ilmuan untuk memposting karya-karya ilmiah sebagai repositori. Dengan begitu karya ilmiah dapat ditemukan di situs 
penerbit, atau homepage para ilmuan. Hasil penelitian ditulis dalam bentuk naskah ilmiah untuk dipublikasikan di jurnal ilmiah merupakan proses yang umum digunakan peneliti di semua ilmu. Artikel ilmiah dengan kualitas tinggi adalah artikel yang ditulis dengan materi yang menarik, informatif, bisa dipakai banyak orang termasuk orang dengan beda disiplin ilmu tertarik membaca .

Ada berbagai macam teks ilmiah sebagai pelaporan hasil yang dicapai selama jangka panjang dalam proyek penelitian. Tetapi publikasi dilakukan secara berkala, sebagai media komunikasi singkat dalam membahas hasil tertentu yang diterbitkan dalam bentuk jurnal. Teks ilmiah ditulis secara singkat dan jelas sesuai masing-masing disiplin ilmu. Tujuan dalam menulis adalah untuk mencapai objektifitas, untuk menghindari penggunaan artefak bahasa, kerancuan istilah, kekeliruan ungkapan dan keangkuhan kalimat yang kurang tepat (Fatchiyah, 2016).

Publikasi ilmiah yang baik dimulai dari memilih jurnal berkualitas, jurnal berkualitas dapat dicirikan dengan adanya terindeks-nya jurnal tersebut seperti google scholar, DOAJ, Acopus, Thomspon and Reuters, jurnal terakreditasi nasional atau internasional sesuai yang dipersyaratkan serta menghindari jurnal predator (Suryana, 2018).

Hasil penelitian harus dipublikasikan secepatnya. Karena saat ini banyak peneliti memikirkan hal yang sama sehingga memungkinkan peneliti dapat mengetahui suatu topik terbaru. Secara umum, tujuan penulisan teks ilmiah adalah untuk 
menggambarkan proses atau hasil yang terjadi ketika melakukan penelitian (Fatchiyah, 2016).

Terdapat beberapa sarana yang dapat digunakan untuk mengkomunikasikan hasil penelitian kepada masyarakat luas yaitu sarana langsung dan tidak langsung. Sarana tidak langsung yaitu peneliti mempublikasikan hasil penelitian melalui media cetak maupun elektronik. Media cetak berupa video, majalah, koran, atau jurnal ilmiah. Selain itu, video, majalah, koran, dan jurnal ilmiah memiliki versi online. Versi online inilah yang disebut sebagai sarana tidak langsung karena harus melalui media elektronik seperti radio atau televisi.

Sedangkan mengkomunikasikan hasil penelitian dengan sarana langsung yaitu peneliti secara langsung mempublikasikan hasil penelitian dengan presentasi kepada responden dalam situasi resmi seperti seminar hasil penelitian atau dalam situasi tidak resmi ssperti ujian Karya Tulis Ilmiah (KTI) (Kristanto, 2018).

1. Perangkat Penunjang Publikasi Penelitian

Publikasi penelitian secara elektronik mengutamakan publikasi paper pada jurnal ilmiah, baik secara nasional manupun internasional. Ada beberapa perangkat yang menunjang publikasi ilmiah, yakni:

a. Google scholar

Google schoolar merupakan sebuah perangkat layanan digital yang dirancang agar dapat menghimpun berbagai publikasi ilmiah secara elektronik oleh penerbit digital (Wahyudin Darmalaksana, 2017). Google schoolar 
merupakan perangkat pengindek publikasi ilmiah. Pada google scholar terdapat statistik tingkat produktifitas publikasi ilmiah dan banyak terdapat mesin pelacak produktifitas publikasi ilmiah. Namun, google scholar dipandang memiliki tingkat selektifitas tertentu atau paling tidak diakui sebagai mesin pengindek yang cukup efektif. Google scholar digunakan untuk evaluasi kinerja publikasi ilmiah bagi Lektor Kepala dan Guru Besar oleh Kemenristekdikti RI (Kementerian Riset, Teknologi, dan Pendidikan Tinggi Republik Indonesia) (Darmalaksana, 2017).

Google Scholar akan membantu seseorang mengidentifikasi penelitian paling relevan dari seluruh penelitian akademis. Google Scholar akan menampilkan kumpulan publikasi yang dilakukan peneliti dengan memperhatikan kelengkapan teks, artikel, penulis, publikasi yng menampilkan artikel, dan frekuensi penggunaan kutipan artikel (Lukman, 2016).

b. Sistem Indeksasi dan Sitasi Indonesia (SINTA)

Setelah google menjadi akun sangat penting yang digunakan untuk evaluasi kinerja publikasi ilmiah, Kemenristekdikti RI membangun portal Sinta (Science and Technology Index). Akun Sinta dan Google Scholar pada dasarnya bersifat personal. Artinya akun dimulai dari pembuatan dan pengelolaan atau update membutuhkan kesediaan dari setiap personal akademisi. Namun cara pembuatan kedua akun dapat mengajukan 
permohonan pendampingan teknis kepada layanan teknis terkait (Darmalaksana, 2017).

SINTA merupakan pusat indeks, sitasi, dan kepakaran terbesar di Indonesia berbasis web yang menawarkan akses cepat, mudah, dan komprehensif untuk mengukur unjuk kerja peneliti dan institusi berdasarkan publikasi yang dihasilkan serta kinerja jurnal berdasarkan jumlah artikel dan sitasi yang dihasilkan. SINTA menyediakan benchmark and analysis, identifikasi kekuatan riset setiap institusi, memperlihatkan kolaborasi penelitian, menganalisis tren penelitian dan direktori pakar. Sistem SINTA dikembangkan untuk mengintegrasikan publikasi dan jurnal yang terbit di Indonesia sehingga dapat dipetakan kinerja penulis, jurnal dan institusi berdasarkan jumlah publikasi dan sitasi yang diperoleh serta peta kepakaran (Lukman, 2016).

c. Scopus

Selain Google Scholar, Sinta mendasarkan pemetaan rekam jejak publikasi pada scopus yang dikenal sebagai institusi pengindeks publikasi ilmiah skala internasional yang bereputasi global. Scopus merupakan perangkat lunak yang memiliki kemampuan memberikan informasi yang luas dan komprehensif tentang jejak publikasi ilmiah internasional (Darmalaksana, 2017).

Scopus merupakan laman produk dari Elsivier yang menyediakan database abstrak dan sitasi puluhan juta 
literatur ilmiah. Dengan scopus, kita dapat melihat peringkat perguruan tinggi atau lembaga penelitian, mutu penelitian, peer review, artikel per fakultas dan sitasi per artikel (Lukman, 2016).

Scopus menerapkan standar baku untuk setiap jurnal yang masuk dalam cakupan indeks-nya. Apabila jurnal tidak memenuhi standar dalam re-evaluation maka jurnal tersebut akan dikeluarkan. Anggota Content Selection and Advisory Board (CSAB) scopus memiliki keahlian terkait materi dan berkomitmen untuk secara aktif mencari dan memilih literatur yang sesuai dengan kebutuhan dan standar komunitas penelitian yang diwakili (Setiyo, Teknik Menyusun Manuskrip dan Publikasi Ilmiah Internasional, 2017).

2. Macam-macam Publikasi

Suatu research bertujuan untuk mengungkap suatu ilmu pengetahuan. Dengan adanya publikasi, maka hasil penelitian akan dibaca oleh para peneliti lain. Oleh karena itu, diperlukan wadah yang dapat menampung hasil penelitian agar dapat dipelajari dan dibaca oleh peneliti lain. Wadah yang dimaksud adalah dengan terpublikasinya hasil penelitian. Berikut adalah macammacam publikasi ilmiah, yakni:

a. Publikasi Melalui Tulisan Ilmiah

Tulisan ilmiah, mencakup tugas akhir, buku atau chapter buku ilmiah, manuskrip jurnal atau artikel, review, dan news letter (Larasati, 2015). 
1) Tugas akhir adalah hasil riset pribadi dan bukan hasil riset orang lain. Tugas akhir berupa disertasi, tesis, dan skripsi (Laila, 2016). Biasanya laporan tugas akhir hanya disusun tetapi tidka dipublikasikan. Laporan hasil penelitian ini hanya dikonsumsi di lingkungan institusi terkait sebagai bahan untuk mengembangkan ilmu pengetahuan dan bahan perumusan kebijakan dan pengembangan pemerintah dalam negeri (Dwiastuti, 2017).

2) Buku atau chapter ilmiah merupakan tulisan yang ditulis dan disusun oleh penulis yang didasarkan pada kajian materi pelajaran atau perkuliahan yang sesuai dengan kurikulum (Laila, 2016). Buku memuat informasi yang spesifik dan hanya membahas satu bidang kompetensi saja dan dapat digunakan sebagai referensi bagi pembaca (Dwiastuti, 2017). Secara garis besar, buku diklasifikasikan menjadi buku referensi (reference book), monograf (monograph), buku ajar/buku teks (textbook), modul, dan bunga rampai (book chapter) (Lukman, 2016).

3) Manuskrip jurnal atau artikel merupakan hasil riset pribadi dan harus originalitas dan dapat berupa hasil riset eksploratif maupun berupa hasil riset penemuan/pembuktian (Larasati, 2015)..

- Klarifikasi dan kriteria jurnal 
Artikel jurnal yang terpublikasi secara nasional telah memiliki ijin publikasi dan dikelola oleh badan ilmiah atau organisasi keprofesian yang disebut jurnal nasional. Sedangkan apabila jurnal nasional telah terakreditasi oleh Dirjen Dikti atau Kepala LIPI maka termasuk jurnal nasional terakreditasi. Selain itu, jurnal internasional merupakan jurnal yang ditulis dalam bahasa resmi PBB yaitu Inggris, Perancis, Arab, Rusia dan Mandarin. Kemudian apabila jurnal internasional telah terindeks pangkalan data internasional seperti Scopus, Web of Science dan telah memiliki impact factor dari SCImago Journal and Country Rank minimum Q3 maka jurnal tersebut tergolong sebagai jurnal internasional bereputasi (Dwiastuti, 2017)

- Penilaian mutu jurnal

Penilaian mutu jurnal sangat penting untuk mengetahui begaimana jurnal dikelola secara profesional sesuai dengan kaidah dan membandingkan dengan jurnal lain. Saat ini ada yang disebut journal metrics sebagai alat ukur untuk melihat dan membandingkan kinerja suatu jurnal. Selain journal metrics ada beberapa hal yang yang dapat 
dipertimbangkan dalam menilai mutu suatu jurnal, yakni: dewan editor, penelaah, Journal Impact Factor (JIF), Scimago Journal Rank (SJR) dan Source Normalized Impact per Paper (SNIP), Citescore, Jumlah publikasi dan presentasi penolakan artikel, akreditasi jurnal, dan indeksasi jurnal.

- Jurnal predator dan lembaga pengindeks palsu.

Jurnal predator dibuat untuk tujuan memproleh keuntungan dan mengabaikan proses penelaahan pakar di bidangnya yang diterima penerbit (Lukman, 2016).

4) Review adalah proses meletakkan, mendapatkan, membaca dan mengevaluasi literatur penelitian yang terkait dengan ketertarikan peneliti (Manzilati, 2017).

5) News letter. Menurut Smith, newsletter adalah publikasi yang dicetak secara periodik dan didistribusikan oleh organisasi kepada publik yang mencari informasi tertentu (Sopian, 2016).

b. Publikasi Melalui Forum Ilmiah

Forum ilmiah dapat berupa symposium, conference, dan scientific meeting. Publikasi forum ilmiah dilakukan dengan cara mempresentasikan hasil penelitian secara oral (lisan) atau melalui poster kepada peserta forum yang pada umumnya adalah akademisi, praktisi, dan ada 
kalanya industri dengan bidang keilmuan yang sama (Setiyo, Teknik Menyusun Manuskrip dan Publikasi Ilmiah Internasional, 2017). Dengan presentasi oral, hasil penelitian memiliki peluang untuk dipublikasikan dalam prosiding baik berupa naskah lengkap maupun extended abstract. Akan tetapi bagi peneliti yang tidak diperkenankan untuk mempublikasikan hasil penelitiannya, maka hasil penelitiannya hanya disampaikan secara oral (lisan) tanpa prosiding (Dwiastuti, 2017). Presentasi oral dilakukan dengan bantuan slaid (slide) dengan durasi 10-12 menit. Secara singkat, presentasi dapat disimpulkan sebagai komunikasi antara penyaji (presenter) dengan sekelompok hadirin (audience) dalam situasi teknis, ilmiah atau profesional dengan tujuan tertentu dan menggunakan media penyajian presentasi yang terencana dengan baik (Lukman, 2016).

Beberapa prosiding internasional yang telah terindeks oleh Scopus dan Thomson Reuter (Web of Science), yakni : IEE Explore (IEEE), Procedia (Elsevier), AIP (American Institute of Physics), CRC Press (Group Taylor and Francis), IOP Conference Series, Atlantis Press, dan Trans Tech Publication (Setiyo, Teknik Menyusun Manuskrip dan Publikasi Ilmiah Internasional, 2017).

Presentasi poster juga menjadi format utama untuk berkomunikasi pada konferensi ilmiah. Pengunjung setiap 
poster relatif kecil jumlahnya karena mereka adalah orang yang tertarik pada bidang iptek. Namun bagi penyaji poster, ini adalah kesempatan baik guna membangun reputasi dan menunjukkan tampilan konservatif yang menarik untuk mengenalkan hasil penelitian sehingga memperoleh sambutan dari pengunjung, bahkan kritik dan saran serta masukan. Poster merupakan sarana yang efektif dan efisien untuk berkomunikasi antara penulis dan pengunjung dibandingkan dengan slaid presentasi. Penulis dan pengunjung lebih mudah berinteraksi dan mengenal identitas dan minat penelitian masing-masing. Berkembangnya teknologi juga berdampak pada penyajian poster. Poster elektronik atau visual menjadi inovasi baruyang dapat menyajikan informasi melalui perangkat elektronik seperti layar proyektor dan multimedia (Lukman, 2016)..

\section{Manfaat Publikasi}

Dengan adanya publikasi, hasil penelitian akan dikenang sepanjang masa. Para peneliti tidak dibolehkan untuk menyimpan atau menyembunyikan hasil penelitian yang telah dilakukan karena hasil penelitian harus dipertanggungjawabkan kepada masyarakat, terutama kepada masyarakat yang terkait ilmiah. Publikasi dilakukan semata-mata bukan untuk memenuhi keinginan peneliti agar menjadi terkenal dan motivasi finansial.

Publikasi dapat terbuka dan tertutup. Publikasi terbuka 
dilakukan karena tidak ada tidak ada sesuatu yang menjadi rahasia atau karena bukan konsumsi masyarakat luas. Selain itu, publikasi terbuka merupakan wujud tanggung jawab para peneliti untuk melaporkan kepada masyarakat tentang apa dan dampak yang mungkin terjadi dari penelitian yang dilakukan. Sedangkan publikasi tertutup hanya dibuat untuk keperluan internal dan bukan untuk konsumsi masyarakat luas. (Timotius, 2017).

\section{Publikasi Jurnal Internasional}

Publikasi internasional adalah saluran untuk menyebarkan hasil penelitian sebagai upaya untuk berpartisipasi ke dalam komunitas ilmiah global. Publikais dapat berupa poster pada pertemuan teknis, komuniasi singkat (short communications), catatan kritis (critical notes), buletin ekstensi (extension bulletins), artikel review (review articles), dan laporan penelitian (research report). Publkasi yang berkualitas (peer review publications) adalah suatu proses di mana sebuah penelitian ilmiah mendapatkan legitimasi, dan diperlukan untuk kemajuan karir di bidang penelitian ilmiah. Jumlah artikel yang telah diterbitkan, dan jumlah kutipan terhadap paper tersebut umumnya digunakan untuk mengevaluasi suatu produktifitas ilmiah seorang peneliti (Soegianto, 2017).

Menurut pedoman operasional penilaian angka kredit kenaikan pangkat/jabatan akademik dosen yang dikeluarkan oleh Kementrian Pendidikan dan Kebudayaan pada tahun 2014, jurnal ilmiah dikelompokkan menjadi dua macam, yakni jurnal 
ilmiah nasional tidak terakreditasi dan terakreditasi. dengan adanya pengelompokkan tersebut, artikel ilmiah memiliki kualitas yang berbeda. Jurnal ilmiah yang terakreditasi memiliki nilai yang lebih tinggi dibandingkan jurnal ilmiah yang tidak terakreditasi. Begitupun dengan artikel yang dipublikasikan di jurnal internasional mempunyai kualitas yang lebih tinggi dibandingkan dengan publikasi jurnal nasional.

Ada beberapa parameter untuk menentukan kualitas jurnal internasional, yakni: terindeks banyak lembaga pengindeks jurnal ilmiah internasional. Beberapa di antaranya ialah Science Scitation Index (SCI) Thomson Reuters, Social Science Scopus, Scimago R, Copernicus, Google Scholar, Directory of Open Access Journals, Astrophysics Data System (ADS), Material Research Database, dan lain-lain.

Ada beberapa alasan para peneliti perlu memublikasikan hasil penelitiannya di jurnal internasional yakni: Pertama, publikasi artikel ilmiah di jurnal internasional merupakan tanggung jawab yang diemban oleh seorang ilmuan baik sebagai peneliti, dosen, akademisi, ataupun profesional lainnya. Publikasi ilmiah bertujuan untuk menyampaikan data terbaru dan orisinal yang diperoleh dalam penelitian serta memberikan kontribusi kemanfaatan kepada masyarakat secara umum dan khususnya masyarakat di bidang keilmuannya. Kedua, publikasi artikel ilmiah akan melindungi karya cipta hasil penelitian dari plagiasi orang yang tidak bertanggung jawab. Ketiga, publikasi artikel ilmiah merupakan bagian dari salah satu syarat kelulusan bagi mahasiswa pascasarjana, khususnya 
mahasiswa program doktor. Keempat, publikasi ilmiah memberikan manfaat untuk diri, institusi pengarang, masyarakat umum, serta bangsa dan negara (Khumaeni, 2017).

\section{E. Hambatan Publikasi di Jurnal Internasional}

Menulis jurnal internasional memang tidak semudah menulis jurnal dengan skala nasional. Banyak hal-hal detail yang perlu diperhatikan dan juga tidak boleh terjadi kesalahan dalam penulisannya. Di Indonesia kurang menjalin kerja sama penelitian ke luar negeri. Beruntungnya saat ini banyak dosen yang sudah menyadari hal ini dan mulai menjalin kerja sama penelitian.

Mengingat pentingnya peran universitas dalam membangun kapasitas penelitian, pertanyaan fundamental yang diajukan adalah: faktor-faktor struktural apa yang menghambat kemajuan penelitian di universitas di Indonesia? (Nughroho, 2016) Selama ini, universitas telah banyak mengkaji faktorfaktor eksternal yang menghalangi kinerja penelitian, seperti kebijakan dan kurangnya dana riset. Namun masih sedikit yang melihat faktor internal, seperti insentif dan ketidakseimbangan beban kerja antara kegiatan pengajaran dan penelitian. Masalah lainnya, kenyataan bahwa penelitian tidak pernah menjadi pilihan karier. Hal ini terjadi bukan saja dalam konteks sosiokultural yang tercermin pada pesimisme terhadap kelayakan penelitian menjadi sebuah profesi, tapi juga tercermin dari bagaimana kegiatan penelitian dianggap kontradiktif dengan 
kegiatan pengajaran di lingkungan universitas itu sendiri. Tampak ada ketegangan antara kegiatan pengajaran dan penelitian di universitas yang berdampak pada terhambatnya kinerja penelitian.

Pemerintah perlu membuat definisi yang jelas mengenai kebutuhan mereka dan membuat prosedur yang mudah bagi penyedia penelitian untuk memenuhi kebutuhan tersebut. Pada satu sisi, sering kali tidak ada kolaborasi antara lembaga pemerintah untuk mengidentifikasi dan mendesain kebutuhan penelitian yang dapat mendukung proses pengambilan kebijakan pembangunan. Pada sisi yang lain, struktur kinerja di universitas tidak menyediakan insentif untuk dilaksanakannya riset yang bermanfaat bagi proses pengambilan kebijakan. Terdapat juga masalah, yakni regulasi membatasi produksi pengetahuan.

\section{F. Insentif Publikasi Internasional}

Kemenristekdikti memiliki program Insentif Publikasi Internasional. program ini bertujuan: (1) meningkatkan motivasi para dosen/peneliti di perguruan tinggi untuk memublikasikan hasil penelitiannya di jurnal ilmiah bermutu bertaraf internasional; (2) memberi penghargaan dosen/peneliti di perguruan tinggi yang telah berhasil memublikasikan artikel ilmiahnya pada jurnal ilmiah internasional bereputasi. Sasaran dari program ini adalah untuk meningkatkan publikasi ilmiah internasional dosen/peneliti di perguruan tinggi serta 
meningkatnya mutu penelitian di Indonesia dan nama Indonesia di kancah peneliti internasional (Lukman, 2016).

\section{G. Etika Publikasi Ilmiah}

Tujuan utama pelaksanaan penelitian adalah pencarian kebenaran ilmiah. Selain itu, tujuan para peneliti membaktikandiri pada pencarian kebenaran ilmiah adalah untuk memajukan iptek, menemukan teknologi, dan menghasilkan inovasi yang bermanfaat bagi peningkatan peradaban dan kesejahteraan manusia. Dengan demikian, para peneliti sebagai ilmuwan dituntut untuk mengembangkan ilmu penegetahuan dan teknologi yang bermanfaat bagi masyarakat.

Dalam melaksanakan tugas tersebut, para peneliti dituntut untuk menjunjung tinggi dan menjaga perbuatan serta tindakan yag bertanggung jawab dalam penelitian. Peneliti sejati memiliki cirri-ciri sebagai berikut : (Lukman, 2016)

- Kemampuan bernalar (reasoning power)

- Originalitas (originality)

- Memori (memory)

- Tanggap dan sigap (alertness)

- Kecermatan (accuracy)

- Persisten (persistent)

- Kemampuan bekerja sama (cooperation)

- Sikap moral (moral attitude)

- Kesehatan (health) 
- Daya kreasi tinggi dan pantang menyerah (zeal)

Tindakan korektif secara ilmiah terkait dengan layanan dan capaian tujuan membangun ilmu pengetahuan, menemukan, dan membahas siapa yang bertanggung jawab atas kekeliruan ilmiah, artinya tanggung jawab dalam penegakan kode etika peneliti adalah sisi lain dari amanah, dan sebaliknya.

\section{H. Promosi Publikasi Melalui Jaringan Media Sosial}

Saat ini banyak situs jejaring sosial daring yang ditujukan untuk akademisi dan periset yang bertujuan memperkenalkan peneliti secara global. Beberapa jaringan sosial akademis memfasilitasi pembuatan kelompok secara daring untuk berdiskusi berdasarkan minat penelitian tertentu. Profil peneliti daring, jejaring sosial, melalui forum daring, dan kolaborasi sejawat periset di Abad ke-21 sangat penting untuk terus dikembangkan sebagai media promosi publikasi yang dihasilkan.

Semua platform jejaring sosial bertujuan melengkapi penggunaan situs jejaring sosial khusus untuk peneliti dan akademisi, misalnya ResearchGate.net dan Akademia.edu. Jadi, Anda dapat berbagi informasi tentang ketersediaan publikasi Anda melalui jaringan sosial; dampaknya ialah kepastian visibilitas global, penggunaan, unduhan, kutipan, dan bantuan yang lebih tinggi dalam meningkatkan skor altmetrik. 
a) ResearchGate.net

ResearchGate.net yang didirikan pada 2008 adalah sebuah jaringan professional yang paling menonjol bagi ilmuwan dan peneliti. ResearchGate.Net merupakan ruang media sosial bagi para peneliti agar penelitian mereka terlihat oleh komunitas peneliti secara global. Setiap peneliti dari bidang studi mana pun dapat dengan bebas menciptakan profil peneliti dan mengunggah makalah kerja dan dataset penelitian yang diterbitkan maupun yang tidak diterbitkan, untuk diseminasi ke seluruh dunia. Peneliti di sini memiliki pilihan untuk mengunggah isi teks lengkap, atau hanya memberikan rincian bibliografi serta menambahkan rincian proyek penelitiannya yang selesai dan sedang berlangsung untuk dibahas lebih lanjut, berdialog dan berkolaborasi dengan anggota jaringan.

\section{b) Academia.edu}

Academia.edu didirikan pada tahun 2008. Sebagai salah satu situs jejaring social terbesar untuk akademisi yang merupakan ruang media sosial bagi para akademisi dan peneliti untuk membuat karya akademis mereka terlihat oleh komunitas akademisi dan peneliti secara global. Setiap akademisi, peneliti, atau dosen dari bidang studi manapun, berafiliasi dengan institusi pendidikan tinggi, dapat dengan bebas membuat profil dan mengunggah makalah, presentasi konferensi, dan kumpulan data penelitian yang dipublikasikan untuk disebarluaskan ke seluruh dunia. Peneliti memiliki pilihan 
untuk mengunggah isi teks lengkap, atau hanya memberikan rincian bibliografi serta mencari kolaborasi akademis, saran profesional dan masukan dari sesama anggota jaringan.

\section{c) Social Science Research Network}

The Social Science Research Network (SSRN.com) diluncurkan pada tahun 1993 oleh Social Science Electronic Publishing Inc., yang berbasis di Amerika Serikat. Ini adalah gudang dokumen untuk penyebaran informasi ilmu sosial di seluruh dunia. Jaringan ini terdiri atas sekitar 22 jaringan penelitian khusus di banyak domain khususnya ilmu sosial, humaniora, dan hukum. Individu, institusi, penerbit, dan masyarakat ilmiah dapat membagikan publikasi dan konten akademis mereka untuk diseminasi global melalui 1 gerbang tunggal.

Situsweb (website) dengan anggota perorangan dan institusional yang tersebar di seluruh dunia menjadikan situs ini sebagai salah satu repositori digital peringkat teratas dengan jumlah akses terbuka (open access) yang signifikan. SSRN menggabungkan artikel dari banyak institusi terkemuka. Setiap anggota individu yang terdaftar bebas mengunggah artikel terbitannya dan konten akademis lainnya serta menyebar luaskannya ke komunitas periset global. Konten teks lengkap yang disampaikan oleh seorang penulis untuk diseminasi global dapat berupa akses terbuka atau pembatasan hak cipta. 
d) Social Networks Penting Lainnya

Saat ini tersedia platform media sosial konvensional yang mendapat perhatian khusus dari penulis, peneliti, dan akademisi. Facebook adalah jejaring social terpopuler. Penerbit jurnal utama, jurnal, masyarakat ilmiah, institusi, organisasi dan penyedia layanan daring semuanya memiliki halaman komunitas masing-masing di Facebook untuk menjangkau aktivitas dan layanan mereka ke masyarakat global. Twitter adalah platform jejaring sosial yang banyak digunakan untuk "microblogging" informasi. LinkedIn adalah platform sosial untuk jaringan profesional. Slideshare adalah komunitas daring terbesar di dunia untuk berbagi dan mengunggah presentasi secara daring.

Individu atau organisasi dapat mengunggah dan berbagi presentasi PowerPoint, PDF, atau OpenOffice serta presentasi video. Selain presentasi, SlideShare juga mendukung dokumen, PDF, video, dan webinar. Figshare adalah platform social untuk berbagi kumpulan data, gambar, dan tabel terbuka. Figshare memungkinkan peneliti untuk memublikasikan semua data mereka dengan cara yang mudah, dapat ditelusuri, dan dapat disamakan. Semua data tersimpan secara daring di Figshare berdasarkan kebijakan lisensi Creative Commons yang paling liberal.

\section{Plagiat}

Plagiarisme dalam penelitian dapat saja terjadi karena 
ketidaksengajaan ataupun disengaja. Plagiarisme sendiri merupakan salah satu tindak kejahatan akademik karena didalamnya terdapat unsur pencurian berupa pencurian ide-ide dan gagasan tanpa mencantumkan sumber aslinya. Perlu diketahui juga bahwa plagiarisme telah membudaya sehingga tentu sangat sulit dihindari apalagi dihilangkan. Sulitnya untuk mengetahui adanya unsur plagiarisme dalam sebuah karya ilmiah, hasil publikasi penelitian dan makalah. Maka perlu kejelasan apa saja yang termasuk plagiarisme atau tidak dalam menentukan suatu karya ilmiah.

Sebagai bentuk perlindungan hukum, pemerintah telah mengeluarkan berbagai kebijakan yang bersifat antisipatif. Salah satunya, secara khusus menerbitkan peraturan menteri pendidikan RI Nomor 17 tahun 2010 tentang pencegahan dan penanggulangan plagiasi, dikatakan:

"Plagiat adalah perbuatan sengaja atau tidak sengaja dalam memperoleh atau mencoba memperoleh kredit atau nilai untuk suatu karya ilmiah, dengan mengutip sebagian atau seluruh karya dan atau karya ilmiah pihak lain yang diakui sebagai karya ilmiahnya, tanpa menyatakan sumber secara tepat dan memadai."

Menurut (Soelistyo, 2011) plagiarisme dibagi atas beberapa jenis: Pertama, plagiarisme kata demi kata (word for word plagiarism). Kedua, plagiarisme atas sumber (plagiarism of source), penulis menggunakan gagasan orang lain tanpa 
menyebutkan sumbernya secara jelas. Ketiga, plagiarisme kepengarangan (plagiarism of authorship), penulis mengakui karya orang lain sebagai karyanya sendiri. Keempat, self plagiarism, penulis mempublikasikan satu artikel atau karya ilmiah pada lebih dari satu media publikasi. Jadi, dapat dipahami bahwa plagiarisme merupakan bentuk kejahatan intelektual karena sama halnya dengan mencuri atau mengambil tanpa seizin pemiliknya. Sebagai manusia biasa, merupakan hal yang wajar melakukan sebuah kesalahan. Namun plagiat tetaplah plagiat. Dan pelaku plagiat harus mempertanggungjawabkan perbuatannya.

\section{J. Mencegah Plagiarisme}

Plagiarisme bukanlah suatu perbuatan yang sulit untuk dicegah. Beberapa upaya telah dilakukan institusi perguruan tinggi untuk menghindarkan masyarakat akademisnya dari tindakan plagiarisme sengaja maupun tidak sengaja. Tindakan plagiarisme secara sengaja maupun tidak sengaja mungkin bisa terjadi pada berbagai keadaan, misalnya tidak mempunyai cukup waktu untuk menghasilkan karya tulis sendiri, tidak mempunyai kemampuan untuk menghasilkan karya sendiri, berpikiran bahwa pembaca tidak mungkin mengetahuinya, dan khusus untuk mahasiswa berpikiran bahwa dosen pembimbing tidak akan mengetahui perbuatan plagiarisme bahkan mungkin tidak peduli, serta berpura-pura tidak tahu dan tidak paham akan plagiarisme.

Salah satu upaya untuk mencegah plagiarisme ialah 
dengan merekam kegiatan penelitian dalam logbook, menyimpa semua arsip rujukan yang digunakan menggunakan aplikasi reference manager, membuat kutipan dan daftar pustaka dengan baik dan benar. (Lukman, 2016) Ada langkah yang harus diperhatikan untuk mencegah atau menghindarkan kita dari plagiarisme, yaitu : (Soelistyo, 2011)

1) Sertakan sitasi

Ketika seseorang menggunaan gagasan, informasi, maupun opini buah piker sendiri, sitasi adalah sebuah keharusan. Hal tersebut juga berlaku meskipun penulis tidak menggunakan kata-kata sama persis. Penyertaan sitasi disini artinya penulis harus memberikan keterangan dari mana informasi yang dituliskan didapat.

Sumber tersebut tidak hanya untuk buku, jurnal, skripsi, atau rekaman audio/visual, namun juga sitasi untuk gagasan dari internet juga harus dicantumkan. Penulisan sitasi juga penting untuk dilakukan ketika penulis merasa ragu dengan keakuratan sitasi informasi yang disajikan. Sitasi dapat berupa bodynote ataupun footnote.

2) Catat berbagai sumber daftar pustaka sejak awal.

Daftar pustaka adalah salah satu kewajiban yang tidak boleh dilupakan ketika menulis karya tulis. Sayangnya, masih ada yang baru mendata ulang daftar pustaka setelah tulisan selesai, hal seperti itu tidak salah, namun sangat berpotensi untuk melewatkan satu, dua, tau beberapa sumber sekaligus. Dalam artian, sitasinya telah tercantum di bodynote atau footnote namun luput dalam daftar pustaka. Dengan mendata 
apa saja sumber yang dipakai sejak awal, kesalahan bisa diminimalisir, pun akan sangat membantu dalam penyusunan daftar pustaka.

3) Lakukan parafase

Tulisan yang hanya menggunakan kutipan langsung lebih berpotensi dianggap melakukan plagiarism. Cara menyikapinya adalah dengan melakukan paraphrase menggunakan susunan kalimat sendiri dari sumber asli dengan tetap mencantumkan sitasi. Paraphrase juga lebih mudah untuk dilakukan sebab formatnya tidak serumit jika menggunakan cara pengutipan langsung.

4) Gunakan aplikasi antiplagiarisme

Apabila penulis masih khawatir dengan hsil akhir karya tulisnya, aplikasi antiplagiarisme dapat dicoba. Dengan aplikasi antiplagiarisme, tulisan yang dihasilkan bisa dibandingkan dengan tulisan-tulisan yang sudah terbit sebelumnya. Aplikasi akan menunjukkan berapa persen tingkat kemiripan yang ditemukan.

\section{K Proses Penerbitan Jurnal}

\section{Menyiapkan naskah}

Setelah nenetapkan suatu jurnal penulis harus nembaca Ains and 
Scope (ruang lingkp) suatu jurnal untuk mengetahi seberapa luas cakparnya. Artinya seber apa baryak topic yang dapat disaj ikan atau diterina dehjurnal tersebut.

2. Pendaahan naskah

Naskah yang dikirinkan ke editor akan næijalari pendaahan sebdum dinyatakan dapat diterbitkan Ada tiga faktor yang saling berkaitan dalamproses pendahaan pada jurnal ilmiah yakri:

a Proses penelaahan. tahap pendaahan yakri: (1) naskah yang lolos sdeks deh editor, telaah deh nitra bestari (revien); (2) nitra bestari menganalisa naskah (mengkritik) dan mentber saran); (3) editor meninta pendis untuk melakkan revisi sesuai dengan saran mitra bestari; (3) revisi naskah ditelaah ulang (4) menunggu proses dari copy/editing

b. Proses pendahaan deh nitra bestari (per review)

- Pendahaan deh nitra bestari untuk pblikasi jurnal paca dasarya merupakan suatu mekarisme kendali atas mitu suatu mitu naskah ilmiah Naskah yang akan dipblikasikan pada suatu jurnal dharapkan bermutu tinggi. Mtra berstari merypakan ahli/pakar pada bidang tertentu yang nengevaluasi hasil kerja penulis setingga diharapkan dapat dipblikasikan dan dapat dipertanggungj anakan secara ilmiah Akan tetapi mitra bestari tidak menentukan diterima atau tidaknya suatu naskah untuk dipblikasikan pada suatuj urnal. 
- Editor jurnal

Ketika sebuah naskah dikrinkan ke suatujurnal, editor akan ntakkkan penapisan naskah secara secara singkat dan memutuskan apakah naskah tersebut akan dikentbalikan kepada pendis atau dikrinkan kepada penelahaah Editor atau devan editor akan menentukan penolakan atau penerimaan suatu naskah dengan merpertinbangkan salah saturya adalah maskan dari kitra bestari.

- Penapisan aval Penapisan anal dilakkan deh editor akan menguntungkan pendis Adapn keuntungan malakkan penapisan amal, yakr: (1) rapid rej ection meskipn menyakiti pendiş tetapi pendakan anal juga menguntungkan penulis untuk segera menperbaik naskahya atau juga untuk nengirinkan ke jurnal laimya; (2) penapisan anal akan nentbantu nitra bestari dalam bekerja karena tidak perlu menelaah naskah yang tidak bermutu

- Pendahaan

Pada umemya ada tiga nodd penelahaan, yakri: (1) single blind pada nodel in pendis tidak nengetahi nama pendaah (2) dable blind pada nodd in baik penelaah maupn pendis tidak saling mengetahi; (3) 
opwn peer-review pada nodd ini penelaah dan penulis saling nengetahui.

- Keputusan akir (final deaision) Jenis keputusan akir naskah ada limæ butir, yakni: (1) accept without any dhange (acoeptanœ), pada tahap in j ưnal akan nemblikasikan naskah tanpa perubahan, (2) acoept with minor revisions (acoeptanœ), jurnal akan nemblikasikan naskah dan nerinta penulis untuk nelakkan perbaikan kedil; (3) acoept after maj or revisions (conditional acoeptanœ), jurnal akan nemblikasikan naskah apabila penulis nemperbaik naskah sesuai dengan saran mitra bertari atau edta; (4) revise and resubmit (conditional rej ection), jurnal masih berkeinginan untuk nempertinbangkan kentbali naskah setelah penulis nelakkan revisi besar (naj or); (5) rej ect the paper (autright rej ection), jurnal tidak akan memblikasikan naskah tersebut ualaupn penulis akan nelakukan revisi.

Unmmya keputusan pertanæ (acoept without any dhanges) jarang terjad. Penulis yang mendapatkam keputusan acoept with minor revisions adalah hasil yang sudah terbaik bagi searang pendis (Lkman, 2016). 


\section{DAFTAR PUSTAKA}

Darmalaksana, w. (2017). Panduan Publikasi Ilmiah:

Perangkat Aplikasi, Standar Penulisan dan Etika Kepengarangan. Jurnal Riset dan Inovasi . 
Dwiastuti, R. (2017). Metode Penelitian Sosial Ekonomi Pertanian: Dilengkapi Pengenalan Metode Penelitian Kuantitatif, Kualitatif, dan Kombinasi Kuantitatif-kualitatif. Malang: Universitas Brawijaya Press.

Fatchiyah. (2016). Strategi Penulisan Artikel Ilmiah. Malang: UB Press.

Khumaeni, E. A. (2017). Kunci SUkses Menembus Jurnal Internasional Bereputasi. Yogyakarta: LeutikaPrio.

Kristanto, V. H. (2018). Metodologi Penelitian Pedoman Penulisan Karya Tulis Ilmiah (KTI). Yogyakarta: Deepublish Publisher.

Laila, M. \&. (2016). Membangun Karsa Menjadi Penulis Populer. Yogyakarta: Deepublish.

Larasati, A. E. (2015). Cara Gaul Menjadi Peneliti For Farmasis: Strategi Pencarian Ide Riset, Managemen Riset, Penulisan Riset, Penelusuran Pustaka, serta Publikasi Ilmiah. Yogyakarta: Deepublish.

Lukman, d. (2016). Pedoman Publikasi Ilmiah. Jakarta: Kementrian Riset, Teknologi, dan Pendidikan Tinggi.

Manzilati, A. (2017). Metodologi Penelitian Kualitatif: Paradigma, Metode, dan Aplikasi. Malang: Universitas Brawijaya Press.

Nashihuddin, W. (2016). Peningkatan Status dan Eksistensi Profesi Pstakawan Indonesia Melalui Publikasi Bidang Kepustakawanan.

Nughroho, Y. (2016). Mengatasi Hambatan Penelitian di Universitas. Knowledge Sector Initiative , 3. 
Setiyo, M. (2017). Teknik Menyusun Manuskrip dan Publikasi Ilmiah Internasional. Yogyakarta: DEPUBLISH.

Setiyo, M. (2017). Teknik Menyusun Manuskrip dan Publikasi Imiah Internasional. Yogyakarta: CV BUDI UTAMA. Soegianto, A. (2017). Penulisan Karya Ilmiah untuk Jurnal Internasional Bereputasi. Surabaya: Airlangga University Press.

Soelistyo, H. (2011). Plagiarisme: pelanggaran hak cipta dan etika. Yogyakarta: Penerbit Kanisius.

Sopian. (2016). Public Relations Writing: Konsep, Teori, Praktik. Jakarta: Gramedia Widiasarana.

Suryana, w. D. (2018). Korespondensi Dalam Publikasi Ilmiah.

Timotius, K. H. (2017). Pengantar Metodologi Penelitian: Pendekatan Manajemen Pengetahuan untuk Perkembangan Pengetahuan. Yogyakarta: ANDI.

Wahyudin Darmalaksana, d. (2017). Analisis Ranking Produk Publikasi Ilmiah Berbasis h-Index Google Scholar.

Wahyudin, W. d. (2016). Penelitian Kompetitif Berbasis Hasil Publikasi Artikel Jurnal (Telaah Rencana Kinerja Psat Penelitian dan Penerbitan). Jurnal Riset dan Inovasi .

Yosua P.W Simaremare, d. (2013). Perancangan dan Pembuatan Aplikasi Manajemen Publikasi Ilmiah Berbasis Online pada Jurnal SISFO. Jurnal Teknik POMITS Vol. 2, No. 3 . 